\title{
Mothers Management of Malaria Fever among Under- Five Nomadic Fulani Children of Northeastern Nigeria
}

\author{
Tidi Stephen Kwabe ${ }^{1, *}$, Olokoba Abdulfatai ${ }^{2}$, Ella Francis Agbam ${ }^{3}$, Abjah Usman ${ }^{4}$, \\ Abdulrahaman Muhammad Bashiru ${ }^{5}$ \\ ${ }^{1}$ Department of Biological Sciences, Federal University Wukari, Taraba State, Nigeria \\ ${ }^{2}$ Department of Medicine, University of Ilorin Teaching Hospital, Ilorin Nigeria \\ ${ }^{3}$ Department of Science laboratory Technology, Benue State Polytechnic, Nigeria \\ ${ }^{4}$ Department of Heamatology, University of Maiduguri Teaching Hospital, Nigeria \\ ${ }^{5}$ Department of Chemical Pathology, Usman Danfodio University Teaching Hospital Sokoto, Nigeria \\ *Corresponding author: steventidik@yahoo.com
}

Received January 17, 2013; Revised April 13, 2013; Accepted April 23, 2013

\begin{abstract}
Malaria is a deadly disease which is spread widely in the tropical regions of the world with holoendemicity in SubSaharan Africa. An investigation of fever management among mothers of under-five children was carried out in nomadic Fulani settlements of Adamawa State Nigeria. Management of fever was assessed through interviews and questionnaires. Nearly half of the nomadic Fulani mothers (49.47\%) did not take any action within 24 hours when their children had fever. This was not significantly different $(\mathrm{p}<0.05)$ with regard to age, clan and parity of the mothers. The duration between mother's recognition and management of fever showed that almost half $(49.6 \%)$ of the mothers did not take time into consideration during intervention of fever. Mothers of under-five who acted within 24 hours of noticing of fever in their children were $30.6 \%$, while those who acted after 24 hours were $12.0 \%$. There was no significant difference $(\mathrm{p}<0.05)$ between mothers recognition of fever and management based on age, clan and parity. Home management of fever by most nomadic Fulani mothers was not satisfactory. Similarly, timely intervention of fever was not considered by most nomadic Fulani mothers. There is the need for appropriate education and adoption of new strategies for timely intervention of disease causing fever among the nomadic Fulani population.
\end{abstract}

Keywords: management, fever, under-five, nomadic Fulanis

\section{Introduction}

Malaria is one of the most severe public health problems and a leading cause of disease and death in many developing countries. According to WHO [1], over 3 billion people live in areas at risk of malaria transmission in 107 countries and territories. Between 350 and 500 million clinical episodes of malaria occur every year with at least 3 million deaths annually. About $90 \%$ of cases of malaria worldwide occur in Africa south of the Sahara $[1,2,3]$.

Despite the improved understanding of malaria pathophysiology and its management, childhood morbidity and mortality remains very high particularly due to limited access to health care and increased drugresistance[4].

Malaria is holoendemic in Nigeria with $P$. falciparum as the dominant species [5]. It is the major cause of morbidity and mortality and accounts for over 600 deaths dealy in Nigeria in children less than 5 years of age in rural and semi-urban settlements. It is also the main reason for out-patient admissions, visits to health facilities and is responsible for most deaths of pregnant mothers in Nigeria [6].

Malaria symptoms include fevers, chills, and headache, and muscle pains, enlargement of the spleen, convulsion, and cold sores around the mouth, enlargement of the liver, vomiting, cough and loss of appetite [7,8].

Malaria imposes substantial costs on individuals and their families which includes; purchase of drugs, expenses for travel to, and treatment at dispensaries and clinics, loss of days of work, absence from school, expenses for preventive measures and expenses for burial in case of death [1]. Estimates show that families living in malaria affected areas in Africa may spend up to $25 \%$ or more of their annual income on prevention and treatment of malaria $[9,10]$.

Prompt diagnosis and effective treatment may save lives, but many children still die from severe malaria despite efforts to improve health services and encourage families to seek treatment through health facilities. Many children living far away from health care units die while travelling to the nearest hospital. These deaths due to malaria usually occur in the first 24 hours of hospital admission which highlights the need for early diagnosis, prompt and appropriate management [11]. It is clear that unless effective management of severe diseases is introduced early at the point of first consultation, the huge burden ofmorbidity and mortality from severe diseases such as malaria cannot be arrested. To manage malaria, better ways must be found to complement existing control methods. Improved tools must be developed and solutions 
must be identified to circumvent and combat emerging malaria problems [12]. Case fatality from severe malaria varies from one place to the other in endemic countries, depending upon facilities available and the time of management.

Malaria management has exceeded a simple biomedical vision of health, in that parents and non- medical community sectors are now involved in the management of the disease [1]. This mode of intervention against malaria will improve community-based health care delivery system. The family is known to be the first hospital for any child with high fever in Africa. Improved home management of malaria will have a significant reduction in the morbidity and mortality due to the infection $[1,13,14]$.

It is a concern that poor diagnosis of malaria continues to hinder its effective management due to the over use of anti-malaria drug leading to resistance. The World Health Organization recommends that anyone suspected of having malaria should receive diagnosis and treatment with an effective drug within 24 hours of the onset of symptoms. When the patients do not have access to a health care provider within that time period (as the case for most patients in malaria endemic areas) home treatment is acceptable [1].

The nomads have an estimated population of 75 million in the developing World; over $60 \%$ of them are in Africa spread over more than twenty one countries. They migrate periodically with their herds to exploit resource (pasture and water) [15]. During the wet season when superficial water and pasture are abundant, nomads disperse over large areas of land while in the dry season; they tend to concentrate around wells, rivers, lakes or man-made ponds [16]. In West Africa, nomads may travel thousands of miles in search of pasture for their animals, often within tribal and clan boundaries [17]. Although they contribute to the national economies of their countries and are the major producers of milk, meat, and other animal products in many African countries [16], they have less access to health care, safe drinking water and formal education; and usually more exposed to diseases, such as malaria, than the settled population [18]. Akogun, et al. [19,20], reported that government programmers in Nigeria to Roll Back Malaria through health education, chemotherapy, insecticides and treated bed nets is yet to be felt by the nomadic Fulanis even though they are in greater risk than any other tribes because of their life style, yet are less served by government intervention programmers. They may remain reservoirs for fresh infections when the entire population is regarded as free.

There is a concern that very little is known about the epidemiology and management associated with malaria disease in the rural communities compared with urban and semi-urban areas [21,22]. In modern times managing malaria could mean treating the infection using antimalarial drugs [23,24]. Various anti-malarialdrugs abound both local and scientific preparations, and these are used by people to control malaria [25]. Aribodor, et al. [26] reported the management of malaria in Asia rural community of Anambra state which includes the use of traditional medicine from local healers, the buying of antimalarial from drugs shops without the prescription of a physician or attendance at local hospitals, and few who do not manage malaria at all. In coastal area of Lagos, management of malaria by mothers elicited a lot of responses such as the use of chloroquine alone, antibiotics, and use of local herbal preparations made from varieties of indigenous leaves, roots, and barks of trees (agboiba). Their knowledge of laboratory diagnosis of malaria is poor [27]. The attributes and kinetic of the disease differ in relation to geographical and ethnic variations $[28,29,30]$. At the very moment, very little is known about the management of malaria in under-five nomadic Fulanis children in Adamawa State, Nigeria.

\section{Objective}

This study is aimed at enriching the management of malaria symptoms by mothers of under-five nomadic Fulanis children.

\section{Methods}

\subsection{Study Area}

The study was conducted in Adamawa State, Nigeria. Adamawa state is located in the north-eastern Nigeria between latitude $7^{\circ}$ and $11^{\circ} \mathrm{N}$ and between longitude $11^{\circ}$ and $14^{\circ} \mathrm{E}$. Adamawa state has four pastoral blocks and livestock movements. The Hong-Michika block, JadaMayo Belwa block, Toungo block and Benue-trough block. The Benue-Trough block is the largest block occupying $11,000 \mathrm{sq} \mathrm{kms}$, making up to $40 \%$ of the pastoral blocks (Figure 1). The Benue pastoral block is a grassland area characterized by the flood plains of the Benue River and that of its tributaries such as rivers Gongola, Kilange and Ine. As a tropical region, the area has two seasons. The dry season starts from November and ends in March; and the rainy season starts in April and ends in October with a mean annual rainfall between 900 and $1100 \mathrm{~mm}$ and an average minimum temperature of $18^{\circ} \mathrm{C}$ and an average maximum temperature of $37^{\circ} \mathrm{C}$. The hottest months are March and April with maximum temperature of $40^{\circ} \mathrm{C}[13]$.

\subsection{Study Population}

The nomadic camps are located in the Benue-trough pastoral block at the confluence of rivers Benue and Gongola in Adamawa State, Nigeria spread across four local government areas (Demsa, Numan, Lam urde and Shelleng) (Figure 2). With an open vegetation of shrubs and herbaceous plants much favored by animals, the extensive Savannah irrigation scheme that provides foliage and availability of water for domestic and animal use; the Benue-trough pastoral block is conducive for the nomadic Fulani in dry season and serves as a major campsite and stop post in the nomadic North-South migration (Figure 1). The nomads are located in bush encampments in the Benue-trough pastoral block. They live in huts and sleep on raised. platforms made of woods. The nomads are surrounded by grasses, water ponds, streams and rivers. Such water sources serve as breeding sites for various disease vectors [10]. The study covered twenty three camps (11 in the rainy season and 12 in the dry season) spread across the Benue-trough pastoral block.

\subsection{Pre-Survey Contact and Mobilization}


The procedures described by Akogun et al. [19,20] was used The organization that is working with the nomads; the Common Heritage Foundation, Yola, was first contacted to get access and seek information on the strategy for approaching the nomads. Informal visits and discussions were made with the camp leaders in the market places where many nomads mingle, and as well as in the camps. The visits were to negotiate and develop confidence with the camp leaders and the community as well as gain acceptance. This was necessary to ensure maximum co-operation from the nomadic Fulanis, and this was successfully carried out. The informal discussion was to know the most common diseases among the nomads with regard to knowledge on the causes, symptoms, severity and management. The informal discussion was helpful in the development of tools for data collection.

\subsection{Determination of Fevers}

In order to determine the number of under-five children that were ill, demographic data of each under-five child was first recorded which included: age, sex, clan, household number and camp code number. Thereafter, structured questionnaires on the symptoms of fever (hot body, vomiting, shivering, unable to drink and eat, convulsion, tiredness, diarrhoea and others) and its episodes in the last 12 months were administered to 272 nomadic Fulani mothers.

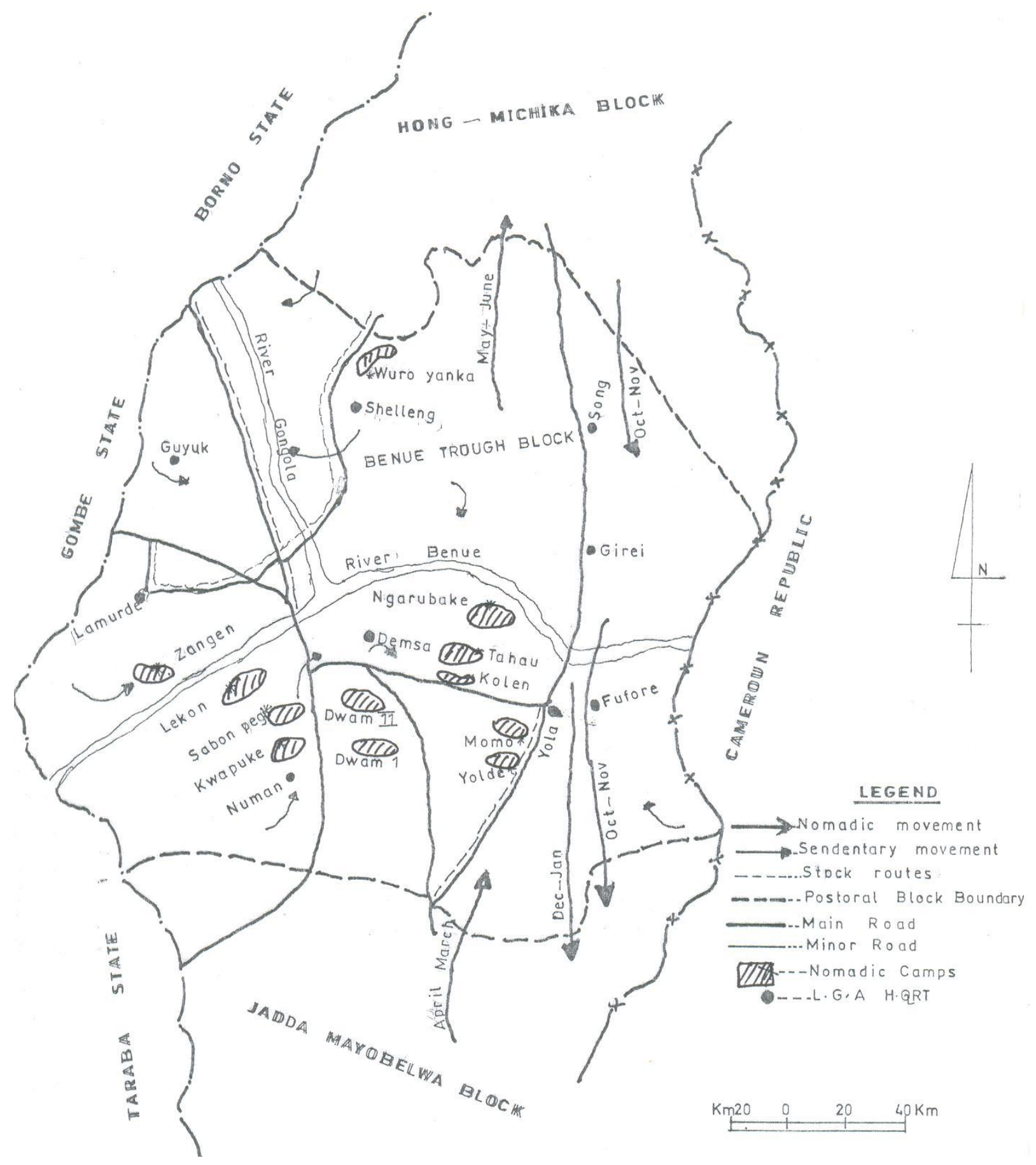

Figure 1. Map of Benue-trough pastoral block showing the nomadic camps and sampling sites 


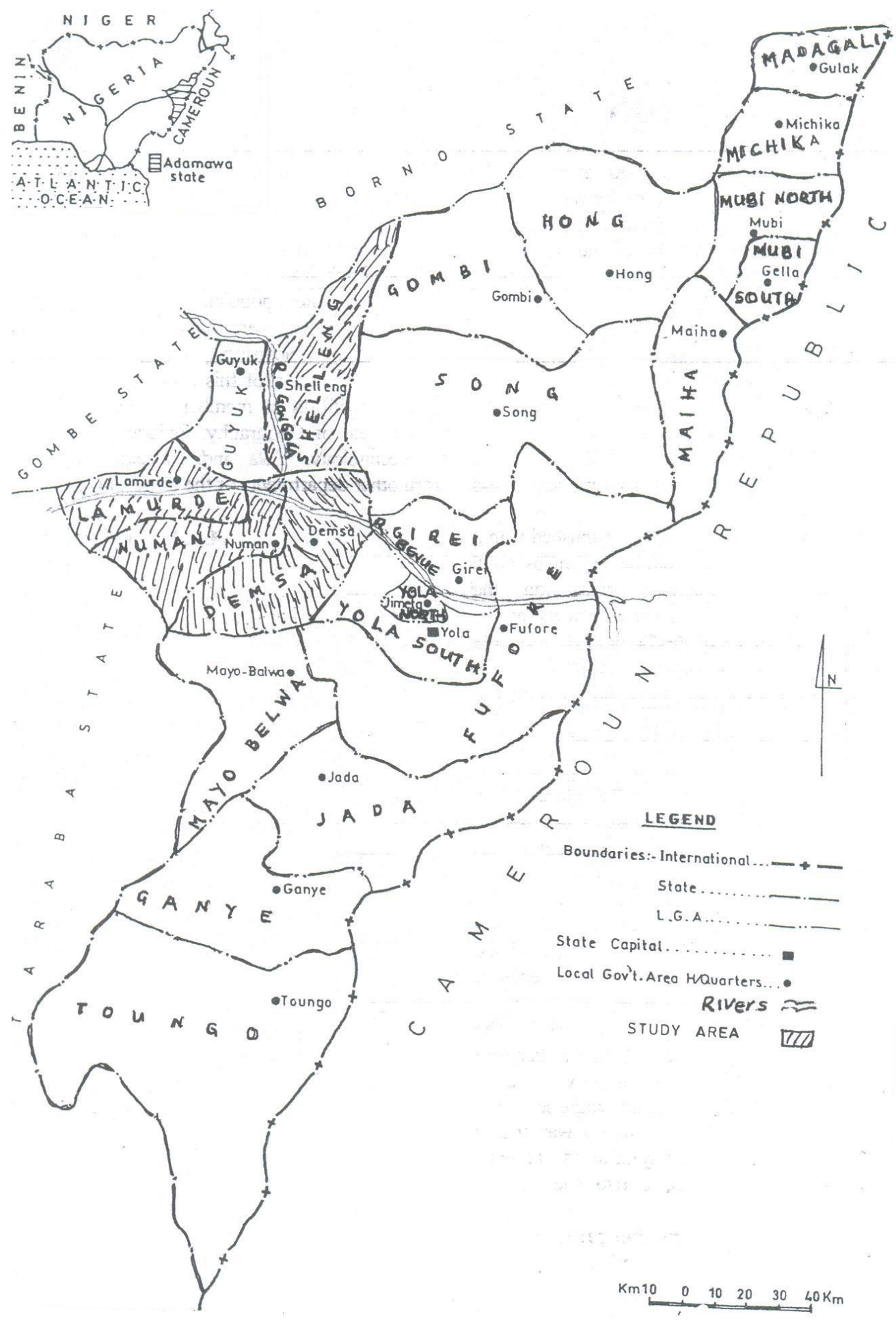

Figure 2. Map of Adamawa State showing the local government study areas:-Demsa, Numan, Lamurde and Shelleng [Adebayo and Tukur, 1999]

\subsection{Ethical Considerations}

Ethical clearance was obtained from Adamawa State Ministry of Health, Nigeria.

\subsection{Data Analysis}

Data were entered into a database created in Epidata version 3.1. Data was then transferred to Statistical Analysis System (SAS) version 8.0 and were analyzed. Pearson chi-square was used to measure the association between the variables. Statistical significant difference were indicated by $\mathrm{p}<0.05$ and no statistical difference by $\mathrm{p}>0.05$.

\section{Results}

\subsection{Management of Fever}

Age, sex and parity-related management of fever symptoms in under-fives are presented in Table 1 . Nearly half of the nomadic Fulani mothers $(49.47 \%)$ did nothing within the first 24 hours of noticing fever in their children. Others $(40.2 \%)$ gave drugs at home, visited chemist shops (5.8\%), government-owned clinics $(3.1 \%)$, do tepid sponging $(1.5 \%)$, gave herbs and visited traditional healers $(0.4 \%$ each respectively). More than half $(66.7 \%)$ of the nomadic Fulani mothers who did nothing for the 
management of fever were between the age group of 3645 years. However, it was not statistically significant $\left(\mathrm{X}^{2}\right.$ $=1.616, \mathrm{df}=3, p>0.05)$. Also more than half $(60.0 \%)$ mothers of the under-fives who gave drugs at home were between the age group of $\geq 46$ years. The use of herbs $(0.8 \%)$, visit to chemist shops $(9.8 \%)$ and visit to traditional healers $(0.8 \%)$ were more observed among mothers of age group 15-25 years, while visit to government-owned clinics $(4.6 \%)$, private clinics $(1.8 \%)$ and tepid sponging $(3.7 \%)$ were more commonly observed in age group26-35 years. Similarly, half $(50.0 \%)$ of the Kiri and Jahun clan did nothing for the management of fever in under-five children. However, the differences was not statistically significant $\left(\mathrm{X}^{2}=0.038, \mathrm{df}=2, p>0.05\right)$. The Jahun clan responded better $(45.7 \%)$ to fever management at home, followed by Kiri clan (39.0\%) and the least was among the Kitaku clan $(31.0 \%)$. The use of herbs $(2.4 \%)$, tepid sponging $(7.1 \%)$, and visit to chemist shops $(19.0 \%)$ were more considered by Kitaku clan than any other clan. Obtaining management from the private clinics (2.4\%), government-owned clinics (4.9\%) and traditional healers $(0.8 \%)$ were more reported by the Kiriclan. The proportion of nomadic Fulani mothers who did nothing was higher $(83.3 \%)$ among the group with parity $\geq 10$, although there was no significant difference $\left(X^{2}=5.919, \mathrm{df}=5, p>0.05\right)$.

\begin{tabular}{|c|c|c|c|c|c|c|c|c|c|c|}
\hline $\begin{array}{c}\text { Age(Yea } \\
\text { rs) }\end{array}$ & $\begin{array}{c}\text { No. } \\
\text { Examine } \\
\mathrm{d}\end{array}$ & $\begin{array}{c}\text { Did } \\
\text { nothing } \\
(\%)\end{array}$ & $\begin{array}{c}\text { Give } \\
\text { herbs } \\
(\%)\end{array}$ & $\begin{array}{c}\text { Give } \\
\text { drug @ } \\
\text { home } \\
(\%)\end{array}$ & $\begin{array}{l}\text { Visit } \\
\text { govt. } \\
\text { clinic } \\
(\%)\end{array}$ & $\begin{array}{l}\text { Visit } \\
\text { private } \\
\text { clinic } \\
(\%)\end{array}$ & $\begin{array}{c}\text { Tepid } \\
\text { sponging } \\
(\%)\end{array}$ & $\begin{array}{c}\text { Visit } \\
\text { chemist } \\
(\%)\end{array}$ & $\begin{array}{c}\text { Visit } \\
\text { tradition } \\
\text { al healer } \\
(\%)\end{array}$ & $\begin{array}{c}\text { Others } \\
(\%)\end{array}$ \\
\hline $15-25$ & 143 & 48.1 & 0.8 & 39.1 & 2.3 & 0.8 & 0 & 9.8 & 0.8 & 0 \\
\hline $26-35$ & 110 & 49.5 & 0 & 41.3 & 4.6 & 1.8 & 3.7 & 1.8 & 0 & 0 \\
\hline $36-45$ & 13 & 66.7 & 0 & 33.3 & 0 & 0 & 0 & 0 & 0 & 0 \\
\hline \multicolumn{11}{|l|}{ Clan } \\
\hline Kiri & 130 & 48.8 & 0 & 39.0 & 4.9 & 2.4 & 0 & 4.9 & 0.8 & 0 \\
\hline Kitaku & 43 & 50.0 & 2.4 & 31.0 & 0 & 0 & 7.1 & 19.0 & 0 & 0 \\
\hline Jahun & 99 & 50.0 & 0 & 45.7 & 2.1 & 0 & 1.1 & 1.1 & 0 & 0 \\
\hline \multicolumn{11}{|l|}{ Parity } \\
\hline 1 & 17 & 66.7 & 0 & 11.1 & 0 & 0 & 0 & 22.2 & 0 & 0 \\
\hline$\geq 10$ & 6 & 83.3 & 0 & 16.6 & 0 & 0 & 0 & 0 & 0 & 0 \\
\hline Total & 272 & 49.4 & 0.4 & 40.2 & 3.1 & 1.2 & 1.5 & 5.8 & 0.4 & 0 \\
\hline
\end{tabular}

The proportion of nomadic Fulani mothers who managed fever at home was higher among the group with parity 6-7 (52.6\%) when compared to other parity groups. Majority of those who visited government-owned clinics and applied tepid sponging (6.3\% each) was higher among mothers of 8-9 parity. The nomadic Fulani mothers who visited chemistshops were more(22.1\%) among mothers that had 1 parity. It was also observed that those who gave herbs $(1.1 \%)$ were higher among mothers of 1 parity.

\subsection{Recognition, Duration and Management of Fever}

Table 2 shows the duration between mother's recognition and management of fever. Almost half (49.6\%) of the mothers did not take action against fever. Mothers of under-five who acted within 24 hours of recognizing symptoms of fever in their children were $30.6 \%$, while those who acted after 24 hours were $12.0 \%$. It was observed that most $(66.7 \%)$ of the mothers who did not take action at any specific time were between the age group of 36-45 years and the least were between the age group of $\geq 46$ years. The mothers age was not a significant $\left(X^{2}=9.396, \mathrm{df}=9, p>0.05\right)$ influence on the time action was taken for the management of fever. Majority of the mothers who acted within 24 hours' time frame were between the age group of $15-25$ years $(31.8 \%)$. It was observed that mothers who acted after 24 hours were between the age group of $\geq 46$ years $(40.0 \%)$. There was a gradual increase of the rate of time action was takenafter 24 hours with increase in age of the mothers.

It was observed that over fifty percent $(51.1 \%)$ of the Jahun clan did not take any action against fever in their children. However, the clan of the mothers was not a significant $\left(\mathrm{X}^{2}=7.443, \mathrm{df}=6, p>0.05\right)$ influence on the time action was taken against fever in children. The Jahun clan has acted more $(31.9 \%)$ within 24 hours after noticing fever as compared to the Kitaku $(31.7 \%)$ and Kiri clan $(29.3 \%)$. It was observed that $16.3 \%$ of the Kiri clan acted after 24 hours of noticing fever in their children.

Table 2. Duration between mothers' recognition and management of fevers.

\begin{tabular}{ccccc}
\hline Parameters & $\begin{array}{c}\text { No. } \\
\text { Interviewed }\end{array}$ & $\begin{array}{c}\text { Did } \\
\text { nothing } \\
(\%)\end{array}$ & $\begin{array}{c}\text { Acted } \\
\text { within24 } \\
\text { hrs } \\
(\%)\end{array}$ & $\begin{array}{c}\text { Acted } \\
\text { after } \\
24 \text { hrs } \\
(\%)\end{array}$ \\
\hline Age(Years) & 143 & 47.7 & 31.8 & 9.8 \\
$15-25$ & 110 & 50.5 & 31.2 & 12.8 \\
$26-35$ & 13 & 66.7 & 16.7 & 16.7 \\
$36-45$ & 6 & 40.0 & 20.0 & 40.0 \\
$\geq 46$ & 130 & 48.8 & 29.3 & 16.3 \\
Clan & 43 & 48.8 & 31.7 & 4.9 \\
Kiri & 99 & 51.1 & 31.9 & 9.6 \\
Kitaku & & & & \\
Jahun & 17 & 66.7 & 11.1 & 0 \\
\hline Parity & 103 & 51.5 & 27.7 & 14.9 \\
1 & 91 & 48.9 & 34.1 & 9.1 \\
$2-3$ & 39 & 42.1 & 34.2 & 10.5 \\
$4-5$ & 16 & 37.5 & 43.8 & 18.8 \\
$6-7$ & 6 & 83.3 & 0 & 16.7 \\
$8-9$ & 272 & 49.6 & 30.6 & 12.0 \\
\hline 10 & & & & \\
\hline Total & & & & \\
\hline
\end{tabular}

The time action taken against fever by parity showed that mothers of Parity $\geq 10$ responded more $(83.3 \%)$ in doing nothing. Although, there was no significant difference $\left(\mathrm{X}^{2}=16.680, \mathrm{df}=15, p>0.05\right)$. Time an action was taken within 24 hours was higher among parity group of $8-9(43.8 \%)$. Similarly mothers between parity groups 
of 8-9 who sought for the treatment of fever after 24 hours were more $(18.8 \%)$ as compared to others.

\section{Discussion}

\subsection{Management of Fever}

Half of nomadic Fulani mothers did nothing for management of fever in their children because of the believe by the nomadic Fulanis that malaria fevers do not require treatment. This believe may increase the prevalence of malaria and its underlying effects. Lack of access to treatments due to poor road network, unfriendly health providers, lack of drugs in the health facilities, and poor economy of the consumers can be other reasons for doing nothing to manage fever by nomadic Fulani mothers.

Regardless of the age groups management of fever was not different; implying that nomadic Fulani mothers apply similar approach to disease interventions, probably due to health services that are most available to them. Mothers that are younger than 46 years managed fever more at home with drugs, probably these age group of mothers have received interventions of the disease, which is the current strategy for disease control especially malaria. Also it may be due to the fact that mothers of these age groups had more freedom to interact and willingly accept any intervention programs that was introduced to them.

There was no difference in the management of fever based on clan of the nomadic Fulani mothers. This is probably because they interact together under the auspices of Meyetti Allah (assembly of the nomadic Fulanis), and may acquire and share similar experience of disease interventions. However, the management of fever at home was more among the Jahun clan who are probably more curious and consistent in accepting intervention commodities supplied to them. Theclan that was least involved in home intervention of disease was Kitaku, because they do not have direct access to the intervention commodities which is in the hand of the Kiriclan in the camp. The use of herbs, tepid sponging and visit to the chemist shops were more considered for the management of fever symptoms by the Kitaku clan. This maybe because these facilities are accessible and do not require any protocols. The use of herbs by the Kitakuclan may not be unconnected with the general belief that herbs are better than the orthodox medicines. The higher visit to chemist shops by the Kitakuclan may be due to the fact they do not want to spend money in visiting clinics or government-owned hospitals where list of comprehensive drugs will be administered for payments, which they may want to avoid. It could also be due to the proximity of the chemist shops which does not require any protocols before services can be rendered. Adams et al. [31] reported that managing malaria fever has been shown to be related to cost, availability and cultural beliefs about the causes of disease. The reported high patronage of chemist shops by the Kitaku clan when compared to other clans may also be linked to the convenience of service and accessibility of drugs from the patent medicine stores.

Management of fever in private clinics, governmentowned hospitals and traditional healers were more patronized by the Kiri clan. This may not be unconnected to the general belief that medical attention is more readily given in the private clinics than other health facilities. Similarly, the higher patronage of government-owned clinics by the Kiri clan may be due to the wider believe that the government hospitals has better manpower, drugs and infrastructure than others. Higher visit to the traditional healers by the Kiriclan may be due to the spiritual linkage of illness in the African traditional set up. The question "why me" which is linked to the traditional believe may not require orthodox medicine. Results of the study show that there was no significant difference between management of fever and parity of the mothers, implying that the differences in parity to fever intervention was similar, may be because they have similar knowledge and orientation towards health intervention programmes. Mothers who gave drugs at home for their children were higher among the parity group of 6-7 probably because of their previous experience which they have acquired with other children whom they have treated of fever, and will want to make a trial with home management. The availability of genuine blister packaged Arthemisininbased combination therapy (ACT) antimalarial supplied to the nomads for the management of malaria may be another reason for higher interventions of fever by group with parity of 6-7 at home. The World Health Organizations [1] recommended that parents and nonmedical community sector can be involved in the management of diseases such as malaria. Improved home management of fever will have a significant reduction in the morbidity and mortality due to malaria infection [13]. Majority of the mothers who gave drugs to their children at home were less than 46 years. Agyepong [32], Nebe, et.al. [27] and Akogun et al. [33] reported that personal experience by mothers play a significant role in the interventions of fever. Another method practiced to reduce the intensity of fever was tepid sponging, thus reducing the risk of convulsion in under-five children. This is in consonance with the findings on malaria management in Nigeria by Oshikoya and Senbanjo [34] and, Ajayi and Falade [35] who reported that the use of tepid sponging at home by mothers have dramatically reduced the fatal effects of malaria fever among children. Results of the study (Table 2) show that mothers who visited government-owned clinics and performed tepid sponging were higher among the group with parity of $8-9$, because they are older mothers of child bearing age with a lot of personal experience, coupled with their freedom to interact with the health officials regardless of who they are, have made them to visit the government-owned clinics with confidence and also perform tepid sponging. The mothers who visited chemist shops and gave herbs for their children were higher among the group with parity of 1, probably these groups of nomadic Fulani mothers shy away from reporting any problem affecting their children, and as such they may prefer to solve their problems in private.

\subsection{Recognition, Duration and Management of Fever}

Half of the nomadic Fulani mothers do not manage malaria in their children on time. This implies that fifty percent of the nomadic Fulani children were not promptly attended to during fever attacks. This may be due to factors earlier mentioned in this study which linked 
malaria fever to adisease of the nomadic Fulanis which does not require any management. However, mothers between the age group of 36-45years do not manage fever in their children on time; probably these groups of mothers are older and may delay to take action in order to observe whether it is a different disease. Majority of the mothers, who manage fever within 24 hours were between the age group of 15-25 years. This may be because mothers between this age group were anxious to take action on their sick children for fear of death. There was a gradual increase in the management of fever with increase in age of the mothers. For example mothers between the age group of $\geq 46$ years manage fever higher after 24 hours. This maybe because they are fewer in this study as majority of them have reached their terminal menopausal child bearing age and may also have few under-five children at the time of this study.

Over fifty percent of the Jahun clan mothers refused to act promptly against fever in their children. However, the clan of the mothers was not a significant influence on the time action was taken against fever in the nomadic Fulani camps, suggesting that irrespective of the nomadic Fulanis clan their action against fever is similar. Despite the similarity in action taken in respect to time, the Jahun clan managed fever promptly within 24 hours, while the Kiri clan acted less promptly within 24 hours. This is probably because the Jahun clan is more concerned to health matters affecting their children than the Kiri clan, despite the fact that both clans had access to the commodities supply for malaria control programme.

Mothers in the group with parity of $\geq 10$ did not manage fever on time, implying that they do not take fever seriously. This may be because they are older with enough experience. It is interesting to note that mothers in the parity groups of 8-9 acted promptly within 24 hours of noticing fever in their children; probably they saw fever as a serious illness in under-five children that requires quick interventions. This in consonance with the report of WHO [1], that any child suspected with fever should receive treatment with an effective drug within 24 hours of the onset of the symptoms, because deaths from malaria fever usually occur in the first 24 hours of admission which highlight the need for early diagnosis, prompt and appropriate management [11]. Hills, et al. [36] reported that delay in seeking for health care facilities was related to deaths of under-five children, due to lack of existence, accessibility, satisfaction, and cost of service. Appearance of illness at night deters individuals from health facilities care, waiting for the day break prolongs the duration of intervention of disease. Other major barriers that grossly affect timely intervention of disease were long waiting time, the attitude of health workers towards healthcare users, behaviour and financial access of the consumers $[37,38]$.

\section{Conclusions}

There is a delay in the timely intervention of fever among nomadic Fulani children implying that a huge burden of morbidity and mortality from severe disease such as malaria may be recorded among the nomads. There is the need for appropriate education and adoption of new strategies for timely interevntion of fever among the nomadic Fulani population.

\section{Competing Interests}

The authors declare that they have no competing interests.

\section{Acknowledgements}

We wish to expressour appreciation to the nomadic Fulani household heads for their co-operation during the study.

We owe appreciation to the Primary Health Care Departments of the Local Government study areas.

\section{References}

[1] World Health Organization. The Roll Back Malaria strategy for improving access to treatment through home management of malaria. World Health Organization, Geneva; 2005.

[2] Breman, J. G. The ears of hippopotamus manifestation, determinants and estimate of the malaria burden.Amer $\mathrm{J}$ TropMedHyg, 64(1-2): 1-11, 2001.

[3] Bryce, J., Boschinpinto, C., Shibuya, K. and Black, R. E. The WHO child Health. Epidemiology Reference group. WHO estimate of the causes of death in children. Lancet, 365:1147-1152, 2005.

[4] Miller, L. H., Baruch, D. J., Marsh, K. and Doumbo, O. K. The pathogenic basisof malaria.Ntr, 415: 673-679, 2002.

[5] Moluneaix, L. and Cramicara, S.Research on epidemiology and control of malaria in the Sudan Savannah of West Africa. The Garth Project, World Health Organization, Geneva; 1980, 125-131.

[6] Salako, L. A.Malaria the unending Saga. Proceedings of the Update symposium on rational use of antimalarial drugs,May and BakerPLC,Ikeja,Nigeria, 1997.

[7] Hughes, S. and Kelly, P. Interactions of malnutrition and immune impairment with specific reference to immunity against parasite.Immunol, 28(11):577-588, 2006.

[8] Cox, S. E., Staalsoe, T. and Arthur, P. Maternal vitamin A Supplementation and immunity to malaria in pregnancy in Ghanianprimigravids.Trop MedIntlHlth,10:1286-1297,2005.

[9] Molta, N. B. Burden of malaria in Africa,. A paper presented at the African Summit on Roll Back Malaria. Abuja Technical Session, 2000. (unpublished).

[10] Taylor, D. W., Zhou, A., Marsillio, L. E., et al., Antibodies that inhibit binding of Plasmodium falciparum-infected erythrocytes to chondroitin sulfate $\mathrm{A}$ and to the $\mathrm{C}$ terminus of merozoite surface protein 1 correlate with reduced placental malaria in Cameroonian women. Infect Immunol, 72:1603-1607, 2004.

[11] Arnaud Dzeing-Ella, Pascal, C. N. O., Rose, T., Timothy, T., Beatrice, M., Monique, M., Ulrich Muller-Roeme, Joseph, J. and Eric, K.Severe falciparum malaria in Gabonese children: Clinical and Laboratory features. Mal J, 4:1-11, 2005.

[12] World Health Organization. Tropical disease Research; Progress $1997-199814^{\text {th }}$ Programme Report of the UNDP/WORLD BANK/WHO special programme for research and training in Tropical disease. WrldHlth Org Bull, 1-10, 1999.

[13] World Health Organization. A strategic frame work for malaria prevention and control during pregnancy in the African region. Brazzaville: WrldHlth Org, 16-21, 2004.

[14] Daniel, M. and Okenu, N.An Integrated Approach for malaria control in Africa. Mal and infect dis in Afr, 3:104-113, 1999.

[15] Omar, M. A. Health care for the nomads.WrldHlth Forum, 13: 307-310, 1992.

[16] Abdikarim, Sheik-Mohammed and Jolian, P. V.Where health care has no access; the nomadic population of Sub-sahara Africa. Trop MedintlHlth, 4 (10): 677-770, 1999.

[17] Lamprey, H. F. Pastoralism yesterday and today: the overgrazing problem in tropical savannah (ed. F. Bouliere), Elseveir, Armsterdam. 643-666,1983. 
[18] Chabasse, D., Roure, C., Rhadby, agRanqueph and Ouilici, M. The health of nomads and semi-nomads of the Malian Gourma; An epidemiology approach in: Population Health and Nutrition in the Sahel 2ndedn. Aghlu.Routledge and Kegan Paul, London; 319$339,1985$.

[19] Akogun O.B, Gundiri M.A, Badaki, J.A., Njobdi S.Y, Adesina A.A, Ogundahunsi, O.T. Febrile illness experience among Nigerian nomads. International Journal for Equity in Health, 11:5, 2012.

[20] Akogun O.B., A.O. Adesina, S. Njobdi, O. Ogundahunsi, OT. Fulani nomadic communities manage malaria on the move. International Journal for Equity in Health, 4: 10-19, 2012.

[21] Lepers, J. P., Deloron, P., Andriamagatan-Rason, M. D. Ramaramiraja, J. A. and Coulange,P.Newly transmitted Plasmodium falciparum malaria in the central high Plateaux of madagascar: assessment of clinical impact in a rural community. Bul. WrldHlth Org, 682: 139-280, 1990.

[22] Anosike, J. C., Nwoke, B.E.B., Onwuliri, C. O.E., Obiukwu, C. E., Duru, A. F., Nwachukwu, M. I., Ukaga, C. N., Uwaezuoke, J. C., Uduji, O. S., Amajuoyi, O. U.and Benjamin, I. N..Prevalence of parasitic diseases among nomadic Fulani of Southeastern Nigeria. AnnalAgricEnviron Med, 11: 221-225, 2004.

[23] World Health Organization. Malaria diagnosis. New perspective. Report of a joint W.H.O./USAID informal consultation. 25-27 October, 1999.Geneva; 2000.

[24] White, N. J. The management of severe falciparum malaria. AmerJ Resp Critical Care Med, 167: 673-674, 2003.

[25] Bonilla, E. and Rodriguez, P. Tropical disease and socio-economic development: the case of malaria in Colombia. Presented at the WHO/PAHO interregional conferenceon malaria. Brasilia. Brazil; 1992.

[26] Aribodor, D. N., Njoku, O. O., Eneanya, C. I. and Onyali, I. O. Studies on prevalence of malaria and management practices of the Azia community, in IhaliaL. G. A., Anambra State, Southeastern Nigeria.Nig JParasitol, 24: 33-38, 2003.

[27] Nebe, O. J., Adeoye, G. O., Agomo, P. U. and Mosanyan, M. E. Malaria in a coastal areaof Lagos state Nigeria:Asurvey of perceptions and practices Amongst mothers/caregivers of children under five years old.Nig JParasitol, 23:69-80, 2002.

[28] Uko, E. K., Emeribe, A. O. and Ejezie, G. C. Pattern of malaria parasitaemia in pregnancy in Calabar.J Med Lab Sc,7: 18-20,1998.

[29] D'allessandro, U., Olaleye, B., Meghuire, W., et al., Reduction in mortalityand morbidity from malaria in Gambian children following the introductionof anational insecticide impregnated bednet program. Lancet, 345 (8948): 479-483, 1995.

[30] Njuguna, P. W. and Newton, C. R. Management of severe falciparum malaria. J Pg Med, 50:45-50, 2004.

[31] Adams, I., omer, E. S. M., Saleh., Khamis, A. H. and Malik, E. M. Perceptions of the causes of malaria and of its complications, treatment and prevention among midwives and pregnant women of Eastern Sudan. J Pub Hlth, 16(2):129-132, 2009.

[32] Agyepong, L. A. Malaria ethno-medical perceptions and practice in an Adangbefarming community and implication for control.SocSciMed, 35: 131-137, 1992.

[33] Akogun, O. B. and John, K. K. Illness related practices for the management of childhood malaria among the Bwatiye people of north-eastern Nigeria. Mal J, 4: 13, 2005.

[34] Oshikoya, K. A. and Senbanjo, I. O. Fever in children: mothers perceptions and their home management. Iran JPaed, 18(3): 229236, 2008.

[35] Ajayi J. A. Health for all by the year 2000.A parasitological dimension for Nigeria. Seminar paper presented at the convocation lecture at the University of Jos; 1992.

[36] Hill, Z., kendali, C., Arthur, P., Kirwood, B. and Adjei, E.Recognizing childhood illness and their traditional explanations: exploring options for care-seeking interventions in the context of the IMCI strategy in rural Ghana. Acta Trop, 8:668-676, 2003.

[37] Nuwaha, F. People's perceptions of malaria in Mbarara, Uganda.Trop Med IntlHlth, 7: 462-470, 2002.

[38] Akogun, O. B. and Akogun, M. K. Human behaviour, water usage and schistosomiasis in small settlement near Yola, Nigeria. Annals of Trop MedParasitol, 90 (3): 302-311, 1996. 